\title{
Do Active Mutual Funds Mimic The Index During A Bull Market?
}

Henry I. Silverman, Roosevelt University, USA

\begin{abstract}
This study seeks to determine whether during a bull market, large actively-managed mutual funds 1) mimic the composition of the $S \& P 500$ Index and 2) mimic the risk attributes of the $S \& P 500$ Index. Employing a panel data set of volatility and MPT statistics for 200 large, activelymanaged US equity and hybrid debt-equity mutual funds between 1995 and 2000, we find no evidence of fund portfolio composition converging toward that of the index. Indeed, as the bull market advances, fund managers move progressively away from holding securities comprising the $S \& P 500$ Index. Our results also reveal levels of fund systematic risk that are lower and significantly different to that of the $S \& P 500$ Index, while fund pseudo-industry risk levels (as proxied by technology holdings) are not significantly different to that of the $S \& P 500$ Index. This suggests that managers mirrored $S \& P 500$ Index technology weights with the purchase of technology firms outside of the Index.
\end{abstract}

Keywords: mimic, closet indexing, active risk, pseudo-industry risk, institutional herding

\section{INTRODUCTION}

63

ver the last 40 years, investment capital in the United States has become increasingly pooled under the direction of professional fund managers. As of June 2009, households had entrusted over $\$ 10$ trillion to investment companies with over $45 \%$ of total assets allocated to higher risk equity and hybrid debtequity funds. ${ }^{1}$

As stewards of this substantial proportion of US wealth, mutual fund managers are increasingly under the scrutiny of shareholders, regulators and researchers for indications as to their investment strategies and risk-taking. This has particularly been the case during extreme bull and bear markets when the sheer magnitude of assets controlled by US investment companies calls attention and occasionally makes them the target of those who argue that security prices are heavily influenced by the trading activities of mutual fund managers. Claims of institutional "herding", "closet indexing", and excessive risk-taking frequently appear in the popular literature. In 1999 for example, the New York Times suggested that growth stocks may have been driven up in price as a result of active fund managers purchasing en masse, the largest-capitalization companies in the S\&P 500 Index so as to profit from the market's momentum. ${ }^{2}$ In another article appearing on CNNMoney.com, Jason Zweig argues that many money managers are so leery of lagging the stock market that they end up copying it, owning similar proportions of the stocks that carry the most weight in the index. ${ }^{3}$

\section{LITERATURE}

According to Jacob (1998), an investment manager's tendency to "mimic" her benchmark index, that is, deviating from it in only minor ways so as to avoid underperforming it, is a widespread activity in the fund management industry. Jacob argues that managers know they will not be fired for simply matching benchmark

\footnotetext{
1 Investment Company Institute, Trends in Mutual Fund Investing, July 2009. Retrieved on August 10 , 2009 from http://www.ici.org/research/stats/trends/trends_06_09

2 "Mutual Funds Report; What's Killing the Value Managers?", The New York Times, (anonymous), , April 4, 1999.

3 Jason Zweig, "What a Mutual Fund Is Really Worth to You", CNNMoney.com, November 1, 2005. Retrieved on April 10, 2008 from http://money.cnn.com/magazines/moneymag/moneymag_archive/2005/11/01/8358879/index.htm
} 
returns so their self-interest is served by minimizing the risk of underperformance rather than maximizing the chance of outperformance. This behavior however, is suboptimal from the shareholder's point of view as she ends up paying the high fees associated with active management but receives only benchmark returns (less fees). Given this theorized conflict of interest between manager and shareholder, one might expect an active fund manager who pursues a strategy of "closet indexing" to face an increased risk of termination, yet Jacob suggests the opposite is true.

Shleifer (1986) reports that stocks newly included in the S\&P 500 Index earn a significant positive abnormal return at the announcement of the inclusion, most of which persists for at least 10 to 20 trading days. Although this may be an informational effect, Shleifer concludes based on the evidence, that the abnormal returns result from excess demand for the shares by pension funds attempting to mimic the return on the S\&P 500 .

Kallinterakis and Ferreira (2006) find evidence of correlated trading toward the composition of the Portuguese PSI-20 Index, particularly between 1996 and 1999, and suggest that this coincides with the Portuguese stock market's boom and bust cycle of that period. Their methodological approach however; does not enable us to determine whether it was primarily institutions or individual investors shifting their asset mix toward the Index.

In a study involving structured interviews with UK equity fund managers, Baker (1998) finds commercial risk - defined as the risk of poor performance relative to competitors - important to 40 percent of the total sample. Pension fund managers in this study perceive external performance measurement as significantly affecting their portfolio decisions, with almost half of the sample replying that it has a "considerable" or "extreme" influence upon security selection. One fund manager interviewed reveals:

If your livelihood depends on the retention of funds and if those funds are being measured by WM [whole market] every 3 months, and if you know that three or four bad quarterly performances are going to cost you your fund, then you tend to reduce and reduce and reduce your exposure to anything outside the Index.

A behavioral phenomenon observed in institutional investors and one which is largely consistent with a tendency to mimic the benchmark index is that of preference for securities that have particular characteristics with respect to size, liquidity, volatility, institutional ownership, financial ratios, etc. ${ }^{4}$ In theory, if all equities are substitutable, there should be no relationship between the level of institutional demand for a stock and that stock's firm-specific factors (Eakins, Stansell, and Buck, 1998). Institutional fund managers however, may need to demonstrate the prudence of their investment decisions in order to reduce the possibility of client criticism and are drawn therefore, to hold shares in companies that are perceived as sound investments (Badrinath, Gay, and Kale; 1989). These researchers find that institutional ownership of a stock is positively related to company size, beta, trading liquidity, and the number of years the stock has been listed.

Lakonishok, Shleifer, and Vishny (1994) show that institutions appear to prefer "glamour stocks", i.e., securities that have high visibility and typically carry low book-to-market ratios. These researchers posit that the previous success of these stocks enables institutions to justify their portfolios to investors. O'Brien and Bhushan (1990) report a positive relationship between institutional ownership and the number of analysts following the stock. Hessel and Norman (1992) find that the debt ratio, $R \& D$ to sales ratio, net operating income to assets ratio, and firm size are all positively associated with the percentage of institutional ownership. Falkenstein (1996) reports that mutual fund managers demonstrate a preference for large company stocks with high liquidity and visibility (as proxied by news stories) and are averse to low-price equities with low idiosyncratic volatility.

These results suggest institutional investors have a distinct preference for the equity of large risky firms as measured by systematic beta and high debt ratios (which can be expected to translate into higher betas). Falkenstein (1996) provides a possible explanation for this risk-seeking behavior with the suggestion that in a bid to deliver higher returns than passively managed index funds (and thereby justify their fees), active managers may invest in especially volatile securities. In an ethnographic study of mutual fund disclosure documents, Silverman (2008)

\footnotetext{
${ }^{4}$ This framework assumes that investment managers are drawn to hold these securities for reasons other than the objectives and constraints explicitly stated in client contracts or prospectuses.
} 
discovers a number of funds which, in an apparent effort to provide superior returns, likely breach their prospectus covenants by overweighting volatile technology stocks in their portfolios. By contrast, Kim, Shukla, and Thomas (1999) report that of mutual funds which deviate from their attributes-based objectives, more than 50 percent shift into a band of lower systematic risk.

Many of the preferred equity characteristics identified in the above empirical studies - low book-to-market ratios, large size, trading liquidity, significant analyst following, high visibility, technology-affiliated - correspond closely with features shared by dominant companies in the S\&P 500 Index. ${ }^{5}$ Large capitalization technology firms like Microsoft and IBM for example, typically have low book-to-market ratios $^{6}$, high R\&D to sales ratios ${ }^{7}$, and are the focus of a great deal of attention from analysts and the press.

\section{METHODOLOGY}

This study seeks to determine whether during a bull market, large actively-managed mutual funds ("large" defined by assets under management), 1) mimic the composition of the S\&P 500 Index, and/or 2) mimic the risk attributes of the S\&P 500 Index. With average annual returns of over $20 \%$ (excluding dividends) as measured by the S\&P 500 Index, we have chosen the period 1995 - 2000 for our study window. The data set consists of a time series of metrics for two-hundred large, actively-managed US domestic equity and hybrid debt-equity mutual funds. This data has been provided by Lipper, a Reuters company, and consists of the following measures for each fund for each month in each calendar year between 1995 and the end of 2000: beta, R-squared, and tracking error against the S\&P 500 Index. The modern portfolio theory (MPT) statistics (beta, R-squared) are estimated by performing a least-squares regression of the fund's return over US Treasury bills (excess return) and the excess returns of the S\&P 500 Index on a monthly basis. A second data sample consists of sector weightings data for 38 mutual funds which also appear in the Lipper database. Sector weightings are reported once annually for each year between 1996 and 2000. This data has been provided by Morningstar, Inc.

Tracking error $^{8}$ is a measure of how closely a fund manager's returns track those of the benchmark index and is generally measured by the variance of excess returns relative to the index (Loftus, 1998). If a mutual fund's composition converges towards that of the index, average tracking error between the two should diminish during the study window. As US mutual funds frequently fail to disclose their target or "best-fit" benchmark index in official communications, convergence/divergence between fund portfolio holdings and that of the S\&P 500 Index was assessed by including in the test sample only those funds with R-squared measures relative to the S\&P500 of greater than .50 in the base year (1995). This ensures a good fit initially with the S\&P 500 and contributes to the meaningfulness of the tracking error values (see the discussion on the significance of R-squared values in Field, 2005).

To address the second question of whether active equity fund managers mimic the risk attributes of the S\&P 500 Index, systematic risk (beta), and factor, or pseudo-industry risk ${ }^{9}$, (proxied by the proportion of the portfolio invested in the technology sector) were measured.

\footnotetext{
${ }^{5}$ Haugen (1995) for example, notes that the S\&P 500 index is dominated by growth stocks, i.e., those with low book-to-market ratios, a sought-after characteristic amongst institutional investors according to Lakonishok, Shleifer, and Vishny (1994).

${ }^{6}$ In July of 2008, the average book-to-market ratio for companies constituting the Dow Jones US Technology Index was .28 as compared for example, to an average book-to-market ratio for firms in the Dow Jones US Industrials Index of .38 and an average book-to-market ratio for firms in the Dow Jones US Consumer Services Index of .46.

${ }^{7}$ See "The 2007 R\&D Scoreboard" published jointly by the Department for Innovation, Universities \& Skills (DIUS) and the Department for Business, Enterprise \& Regulatory Reform (BERR). Retrieved on June 7, 2008 from http://www.innovation.gov.uk/rd_scoreboard/

${ }^{8}$ Tracking error is a measure of the standard deviation of the error terms of a fund's excess return around the sample regression line.

${ }^{9}$ See Elton and Gruber $(1970 ; 1973)$ and Farrell $(1974 ; 1976)$
} 


\section{$4 \quad$ RESULTS AND DISCUSSION}

Five-year bar charts depicting fund-index convergence/divergence (as proxied by tracking error) and fund systematic risk for the test sample of 200 Funds are presented in Figures 1 and 2, respectively. A five-year bar chart depicting mean pseudo-industry risk (as proxied by the proportion of portfolio assets invested in the technology sector) for the subset sample of 38 Funds is presented in Figure 3. The results of a Paired $t$ test comparing mean systematic risk for the test sample and that of the S\&P 500 Index (beta $=1)$ are presented in Table 1. The results of a Paired $t$ test comparing mean technology holdings for the subset sample and that of the S\&P 500 Index are presented in Table 2.

Figure 1: Mean Fund Convergence/Divergence vis-à-vis S\&P 500 Index (1996-2000)

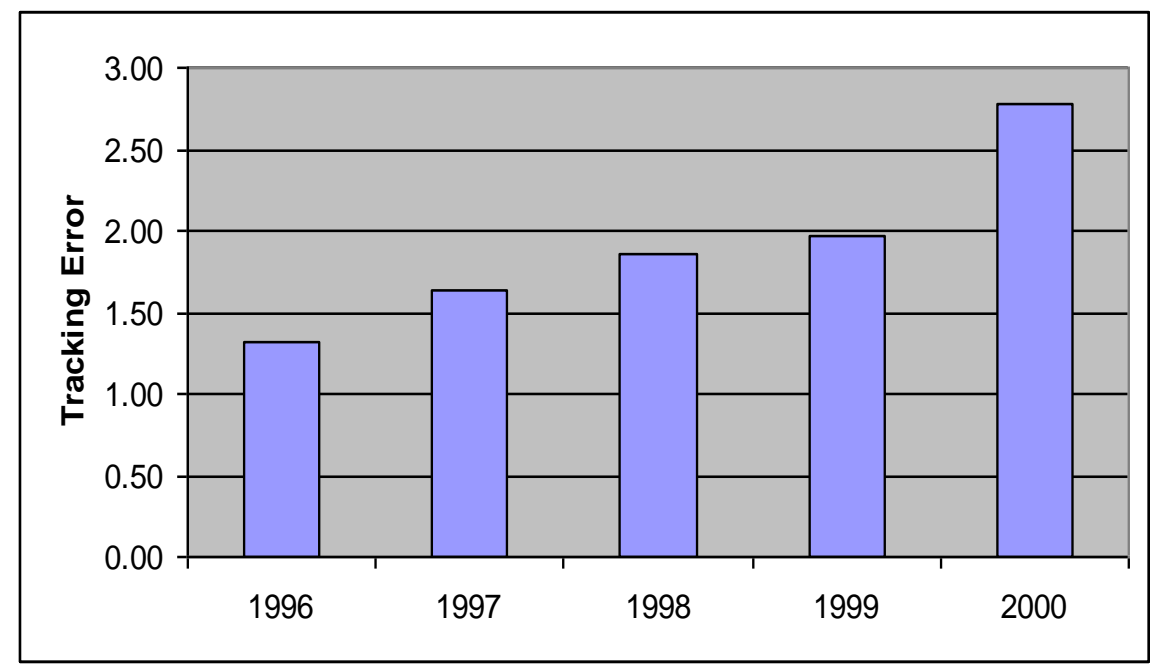

Figure 2: Mean Fund Systematic Risk (1996-2000)

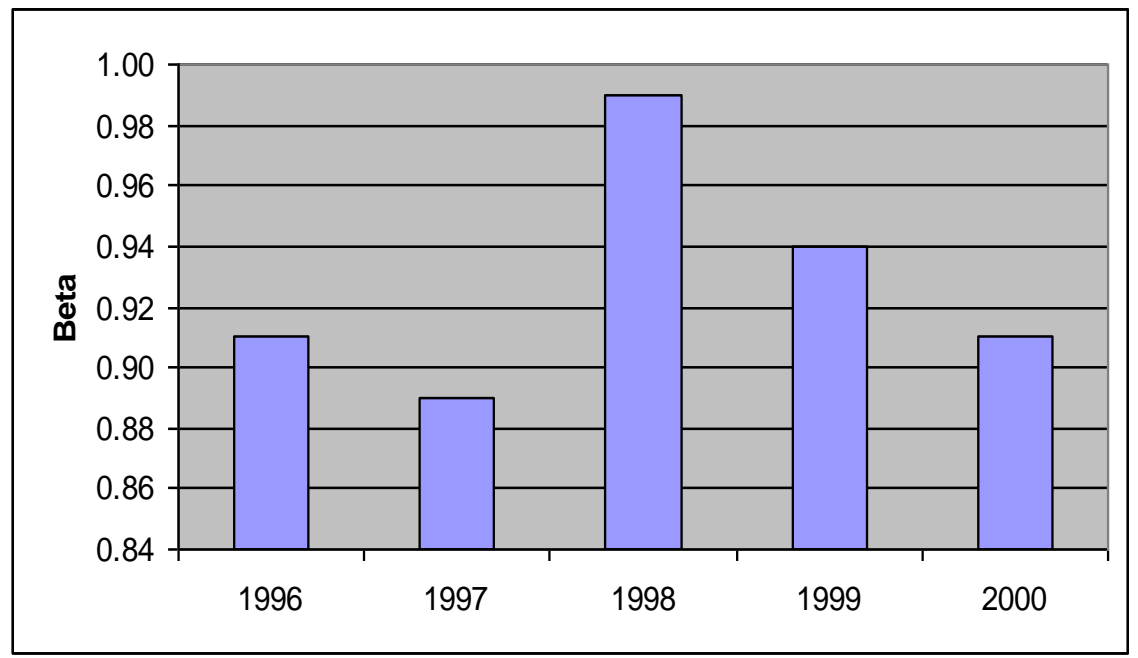


Figure 3: Mean Fund Pseudo-Industry Risk (1996-2000)

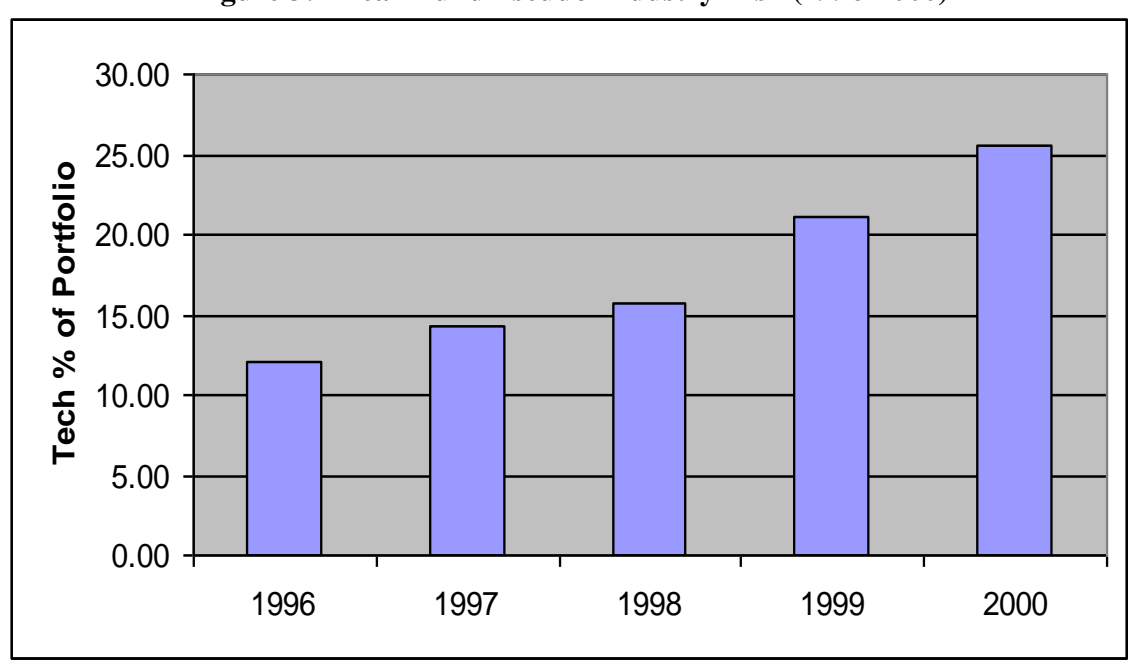

Table 1: Fund/S\&P 500 Systematic Risk Paired $t$ Test

\begin{tabular}{|c|c|c|c|c|c|}
\hline Year & N & Mean & SD & t & Significance \\
\hline 1996 & 200 & .9108 & .2093 & 6.026 & .0001 \\
\hline 1997 & 200 & .8852 & .2110 & 7.693 & .0001 \\
\hline 1998 & 200 & .9871 & .2231 & .8211 & .4126 \\
\hline 1999 & 200 & .9398 & .2411 & 3.532 & .0005 \\
\hline 2000 & 200 & .9108 & .2564 & 4.920 & .0001 \\
\hline
\end{tabular}

Table 2: Fund/S\&P 500 Technology Holdings Paired $t$ Test

\begin{tabular}{|c|c|c|c|c|c|}
\hline Year & N & Mean & SD & t & Significance \\
\hline 1996 & 38 & $12.14 \%$ & .1044 & .126 & .900 \\
\hline 1997 & 38 & $14.27 \%$ & .1046 & 1.460 & .153 \\
\hline 1998 & 38 & $15.70 \%$ & .1056 & -.216 & .830 \\
\hline 1999 & 38 & $21.08 \%$ & .1248 & -4.063 & .000 \\
\hline 2000 & 38 & $25.63 \%$ & .1425 & 1.851 & .072 \\
\hline
\end{tabular}

Mean tracking error rises in each year of the window from a low of 1.32 in 1996 to a high of 2.77 in 2000. Average betas remain below 1.00 in all years and the Paired $t$ test indicates that in all years except 1998, fund systematic risk is significantly different to that of the S\&P 500 at the 5\% level. Average technology holdings rise linearly from a low of 12.14 percent of portfolio assets to a high of 25.63 percent of assets in 2000 . The Paired $t$ test indicates that with the exception of 1999, the mean proportion of technology holdings for the subset sample of funds and that of the S\&P 500 are not significantly different from one another at the $5 \%$ level.

The results do not provide evidence of mutual fund composition converging toward, i.e., "mimicking", that of the S\&P 500 Index. On the contrary, consistently rising tracking error values suggest that fund managers moved progressively away from holding securities comprising the S\&P 500 Index as the bull market advanced.

That active fund managers are observed shifting their portfolio mix away from the mainly large and highly visible growth stocks constituting the S\&P 500 Index, runs counter to both anecdotal claims and research findings discussed earlier where institutional investors appear to demonstrate a preference for shares with these characteristics (see Badrinath, Gay, and Kale, 1989; O’Brien and Bhushan, 1990; Lakonishok, Shleifer, and Vishny, 1994). These earlier studies however, were based on panel data preceding the powerful bull market of $1995-2000$. It may be that during this latter period of spectacular returns on the large indices, fund managers increasingly opted to sell their winners and shift investor monies toward less visible and less richly valued sectors of the stock market. 
Turning to measured risk attributes, while active managers appear to have moved away from holding securities found in the S\&P 500 Index, this was not at the cost of systematic risk in excess of levels for the index. Indeed, mutual fund betas remain below the Index mean of 1.00 each year (significantly so in four out of five years). These results are at variance with those of Falkenstein (1996) noted above but consistent with the findings of Kim, Shukla, and Thomas (1999) who report that of mutual funds which deviate from their attributes-based objectives, more than 50 percent shift into a band of lower systematic risk.

Pseudo-industry risk escalates substantially each year such that by 2000 , average technology holdings represent over 25 percent of assets under management -- double the proportion observed in 1996; however, with the exception of 1999, mean technology weights for funds in the test sample are not significantly different to that of the S\&P 500 Index. That fund technology weightings remained comparable to those of the Index even as tracking error levels rose suggests that active managers expanded their technology holdings with the purchase of technology firms outside of the S\&P 500 Index. This would not be inconsistent with orthodox portfolio management practice whereby fund managers seek to mirror benchmark sector weights while reaching for superior risk-adjusted performance, or alpha, via judicious stock selection within the same industrial sector (see Jacobs and Levy, 1998).

\section{CONCLUSION}

Investment companies in the United States now control a substantial share of household wealth. As the mutual fund industry has grown in terms of assets under management, the popular press and a growing body of academic studies have focused on active equity fund managers in an effort to better understand their investment practices and risk-taking on behalf of shareholders. There has been significant interest in the question of whether fund managers mimic their benchmark index in an effort to avoid underperforming it, whether they demonstrate a preference for securities which share common fundamental characteristics, and whether they expose shareholders to excessive levels of risk in a quest for superior returns. We examine these issues within the context of the bull market of $1995-2000$ so as to discover and trace fund manager behavior during a period when anecdotal evidence suggested that large actively-managed funds may have been engaged in "closet indexing". We find no evidence of fund compositional convergence toward the S\&P 500 Index. Indeed, as the bull market advanced, fund managers moved progressively away from holding securities comprising the Index. Our results indicate that during the study window, mutual funds in the sample closely mirrored levels of pseudo-industry risk (as proxied by average technology holdings) seen in the S\&P 500 but maintained significantly lower levels of comparative systematic risk.

\section{AUTHOR INFORMATION}

Henry I. Silverman is an Assistant Professor of Finance at Roosevelt University in Chicago and a director of an asset management firm based in London. Engaged in research on investment companies, their return objectives, investment strategies, and risk-taking behavior, Dr. Silverman has conducted numerous interviews with US and European fund managers and performed analytic work on their disclosure practices and documents. Dr. Silverman's findings were presented to the Chairman of the British Government's Financial Ombudsman Service in 2003. Dr. Silverman is author of the academic text Theory and Practice of Fund Management and a member of the CFA Institute.

\section{REFERENCES}

1. Badrinath, S.G., G.D. Gay, and J.R. Kale. "Patterns of Institutional Investment Prudence and the Managerial Safety-Net Hypothesis.” Journal of Risk and Insurance (December 1989), 369-382.

2. Baker, Mae. "Fund Managers Attitudes to Risk and Time Horizons: the Effect of Performance Benchmarking." The European Journal of Finance, 4 (1998): 257-278.

3. Eakins, Stanley G., Stanley R. Stansell, and James F. Buck. "Analyzing the Nature of Institutional Demand for Common Stocks." Quarterly Journal of Business \& Economics, 37 (1998): 33-48.

4. $\quad$ Falkenstein, Eric G. "Preferences for Stock Characteristics as Revealed by Mutual Fund Portfolio Holdings." Journal of Finance, 51(1) (Mar 1996): 111-135.

5. Farrell, James. "Analyzing Covariation of Returns to Determine Homogenous Stock Groupings.” Journal of Business, 47(2) (April 1974): 186-207. 
6. $\quad$ Farrell, James. "The Multi-index Model and Practical Portfolio Analysis.” The Financial Analysts Research Foundation Occasional Paper No.4 (1976).

7. $\quad$ Field, Andy. Discovering Statistics Using SPSS. London: Sage, 2005.

8. French, Kenneth R. and Eugene Fama. "The Cross-Section of Expected Stock Returns." Journal of Finance 47(2) (1992): 427-466.

9. Haugen, Robert A. The New Finance: The Case Against Efficient Markets. Englewood Cliffs, New Jersey: Prentice Hall, 1995.

10. Hessel, C. A. and M. Norman. "Financial Characteristics of Neglected and Institutional Held Stocks." Journal of Accounting, Auditing and Finance, (1992): 313-334.

11. Investment Company Institute. "Trends in Mutual Fund Investing, May 2008”. Retrieved on July 15, 2008 from http://www.ici.org/stats/mf/trends 05 08.html\#TopOfPage

12. Jacob, Nancy L. "Evaluating Investment Performance" in Peter L. Bernstein and Aswath Damodaran (eds.), Investment Management. New York: John Wiley \& Sons, 1998.

13. Jacobs, Bruce I. and Kenneth N. Levy. "Investment Management: An Architecture for Equity Market." in Frank J. Fabozzi (ed), Active Equity Portfolio Management. New Hope, Pennsylvania: Frank J. Fabozzi Associates, 1998.

14. Kallinterakis, Vasileios and Mario Pedro Leite Ferreira. "Herding and Positive Feedback Trading in the Portuguese Stock Exchange: An Exploratory Investigation.” Unpublished conference paper, (2006).

Retrieved on March 27, 2008 from http://www.fep.up.pt/conferencias/pfn2006/Conference\%20Papers/594.pdf

15. Kim, Moon, Ravi Shukla, and Michael Thomas. "Mutual Fund Objective Misclassification." Working paper, (July 6, 1999).

16. Lakonishok, Josef, Andrei Shleifer, and Robert W. Vishny. "Contrarian Investment, Extrapolation, and Risk." Journal of Finance, 49 (1994): 1541 -1578.

17. O'Brien, P. and R. Bhushan. "Analyst Following and Institutional Ownership." Journal of Accounting Research 28 (Supplement) (1990): 55-82.

18. Shiller, Robert J. and John Pound. "Survey Evidence on Diffusion of Interest and Information Among Investors." Journal of Economic Behavior \& Organization, 12(1) (Aug 1989): 47-66.

19. Shleifer, Andrei. "Do Demand Curves for Stocks Slope Down?" The Journal of Finance, 41(3) (Jul 1986): 579-590.

20. Silverman, Henry I. "Mutual Fund Risk-Return Profiles: A Novel Use of Triangulation.” Journal of Risk Management in Financial Institutions, 1(2) (2008): 191-222 


\section{NOTES}

